\title{
SPRING POEMS BY A FIFTH GRADE
}

ELSA MILLER

Fifth Grade, Francis W. Parker School

Following is a report of some work in composition done by the pupils of the fifth grade of the Francis W. Parker School.

The class mentioned has heard and read, in its course through the primary grades, much of the best literature and poetry for children. They live in an environment where they come in contact with the best that a city park can give. They make frequent excursions to the woods and lake shore. Many spend summers out in the country, by lake or seaside, or in the mountains. Some hear good literature and poetry read aloud at home. These conditions form a wholesome, helpful fund of observation, experience, and imagination which must find expression.

The first of May in the Francis W. Parker School is a treeplanting day. The children choose some tree, shrub, or vine to plant in some spot on the school grounds which needs beautifying. The planting is attended by a festival with May queen, singing, and dancing. All the children in the school, who wish, write poems, which they read to the school and to the May queen on that day. She selects, with the aid of the teachers, the best one, and favors the author with a May basket. The chosen poem is set to music by some grade, or by individual members of the school, for the next May festival. Every song is sung to the school by the composer, or by a small chorus. Last year the chosen poem was sung with six different musical settings, composed in the regular music periods by the various children. Obviously this festival affords a very natural opportunity for poetical and musical expression, though necessarily the results are crude.

During the spring season the children had opportunity to talk about the numerous signs of spring, the beauty of the early 
spring flowers which they gathered, the sounds which they heard in the woods, the odors of the soft soil which they spaded in the garden and of the new moist grass which they uncovered, and the soft, delicate colors of the season which pleased them. All this work was done without mention of the writing of poetry; in fact, their desire to write came from these talks.

One day it was suggested that they write about what they liked best in the spring time, and, if they chose, write in verse. They immediately suggested that each child write a spring poem for May Day. They stipulated that these poems should be written without signatures and be placed in a basket on the table. They were to be read to the class by the teacher. The majority were eager and ready to write. They worked silently, without question to the teacher or to each other, to avoid influence and suggestion by others. They were allowed to write until they had finished. Some, as the results will show, had little to say, and others were more free in their expression.

Another day the poems were read aloud. After the first reading the children asked to hear some poems re-read. Some began to mark to meter, and detected faults and suggested changes. The teacher then wrote a familiar poem on the board and scanned it. The number of feet in a line was noted. The children scanned parts of many poems which they knew, and discovered how the number of feet in a line varied in different poems, how the length of lines in the same poem varied, and how corresponding lines of stanzas agreed. They wished now to mark their own poems to see whether feet or lines were missing. They consulted one another, and changed a line or a word here and there. The work of every child in the class is given below, and as here presented stands in form as the children corrected it. That is, no actual work was done by the teacher.

Several poems were chosen to be read to the May queen. Later every child read his verses to the school in a regular morning exercise. This required an introduction, which the children wrote with combined effort. The humorist of the class furnished the closing couplet. 


\section{THE POEMS}

\section{A MORNING EXERCISE}

This morning exercise is begun, We hope you'll all enjoy the fun.

We made some rhymes with many lines

To tell you of spring's happy times.

Some thoughts are of the birds and flowers, And some of sun and some of showers.

We hope you'll think of shady bowers

Where you may sit in sunny hours.

- Read by Doris; composed by the grade.

SPRING

The sweetest time of all the year

Is the joyous time of spring,

When grass is green, and skies are clear,

And birds are on the wing.

Now on the banks of laughing brooks

The nodding violet grows,

And every pussy willow looks

Like wee gray kitten's toes.

Hepaticae now push their way

With all their tiny might.

And on their stems of hairy gray,

Hang stars of blue and white.

-Frieda Maynard

SPRING

The days grow warmer and grow bright

And after them a nice spring shower,

To start the little plants a-growing

So's to be green some summer hour.

The mother tree puts on her leaves

To hide the nests the birds have made,

To give us sprigs both fresh and green,

In summer days to give us shade.

-Lucy Dunlap Smith 


\section{SPRING THOUGHTS}

The trees are budding,

The flowers their winter caps throw off.

The bluebirds are singing,

The roses are sending sweet odors aloft.

The sky is blue,

Spring's sun is drying up the dew.

The grass is green

And yellow dandelions gleam.

\section{-Elizabeth Beulah Beckler}

\section{SPRING POEM}

This is the time of year

When birds and flowers are here

In all their beauty.

The buds on the trees burst forth,

Then tiny leaves appear,

And lo, they are dressed in lovely green!

Birds are on the wing, They sing a carol of joyous spring.

-Carlton Prindeville

\section{FOR IT IS MAY}

The days are growing warmer,

The sun is shining bright,

The air is full of light-

For it is May.

The trees are swaying lightly, Their leaves are growing green, Then comes spring's joyous queen.

For it is May.

The robins with their nestlings

Are flitting through the trees

Mid sunshine and the breeze,

For it is May. 


\section{MAY}

May is best of all the year, All things live and grow again; The tree sends out her baby leaves, And birds build nests beneath the eaves.

All the seeds are in the ground, Violets in the field are found;

Ducks are honking overhead, The baby birds cry to be fed.

-Josephine Palmer

\section{SPRINGTIME}

Spring has come

And the children have fun.

The sun is shining

And the flowers are tiny.

The leaves on the trees are green.

-Grant McDonald

\section{SPRING IN THE FOREST}

The grass is green,

The robins are here,

And birds are thick in the air.

The animals hunt,

The wild bears roam

Far away from their native home.

The fields look green,

The trees make shade

In the far away, lonely forest glade.

\section{-Frank Packard}

\section{THE AWAKENING OF SPRING}

The sleepy fields and meadows,

At the call of spring,

Awaken after winter's doze,

And the birds begin to sing, to sing

Of the spring, the glorious spring. 
The cattle all are grazing

In the pastures green,

Their smooth old heads are never raising.

In every flower can be seen

The joy of spring, the glorious spring.

And when the spring is gone,

Comes summer with her beauties

In the garden and on the lawn.

But the spring is best for all.

Oh, the spring, the glorious spring!

-DORIS HuMPhrey

WINTER'S GONE

The cold and frosty winter's gone, The warm and sunny days are here, The little squirrels play all day long

And then we know it's spring.

-Leslie Vaughn

\section{SPRING}

I love the bright warm days of spring,

When the flowers come out and the birds start to sing.

I love the bright warm days of spring,

-James Braithwaite

\section{SPRING}

With May-day comes the lovely spring

The ground is ready for the seed,

The father bird begins to sing;

The mother bird her young does feed.

The robin red-breast, fat and round,

Is tapping softly on the ground, The foolish worm the signal hears, And from the ground he soon appears.

-Leonard Marshall 


\section{SPRING}

When spring comes forth to smile at last,

Then winter must on his way.

When Herald Jonquil blows his blast,

The flowers and leaves awake to sway

In the first warm breeze of May.

Then the robin sings its joyous song,

And the wood-brook runs away,

The bluebell rings its ting-a-tong.

Oh! the thrush comes forth to stay,

Sings as he flies up the southward way.

The violet wafts its fragrance sweet,

The crow he almost sings, but mates

Last of all comes the bobolink late,

Last of all with his mate.

When spring comes forth to smile at last,

Then winter must on his way.

When Herald Jonquil blows his blast,

The flowers and leaves awake to sway

In the first warm breeze of May.

\section{-Katharine Tilt}

\section{SPRING}

Spring has gone

And so has May.

Thus we have no more to say.

-Frederick Gansbergen 